\title{
Research report - Alternative public policies in providing integrated specialized services for children with autism spectrum disorders and for their families
}

\author{
Sergiu-Lucian Raiu•
}

\begin{abstract}
The article is a research report that briefly describes the stages of an advocacy process and the results of the project: "Increasing the involvement of NGOs and social partners in promoting alternative public policies for children with ASD", an initiative of Help Autism Association which took place in 2019. Was used a mixed research methodology. In-depth interviews were collected from 134 specialists from institutions, NGO practitioners and parents of children with ASD. Focus-group were organized in 8 regions of Romania with participation of 139 representatives of the target group of the project. Through the method of the self-administered questionnaire, opinions from 47 specialists and 303 relatives/guardians of people with ASD were collected in order to identify the needs and to propose solutions in the field of providing integrated specialized services for people with ASD. Also 8 working meetings took place in all 8 development regions of Romania with participation of 151 specialists who were informed about the method of Assessing the Impact of Legislative Regulation and 96 representatives of the non-governmental sector were trained in the advocacy process. Following the project, a coalition of 80 non-governmental organizations was formed, reunited in the RO TSA Network. Through this project, the civil society, represented by this network of NGOs participated in the elaboration of the first National Plan on Autism in Romania.
\end{abstract}

Keywords: public policies; NGOs; advocacy; autism; integrated specialized services.

\section{Introduction}

In Romania, until recently, the capacity of NGOs to change public policies was generally low, but in recent years the involvement of civil society in formulating public policies has increased constantly. NGOs and civic groups are becoming progressively important in influencing public decisions. Laws such as 544/2001 on free access to information of public interest and Law 52/2003 on decision-making transparency in public administration are the main advocacy tools that have opened the access of civil society to influencing the decisions of power groups. NGOs influence public policies in two main ways: either when they are openly consulted by government authorities or Parliament and, in these cases, NGOs present the opinions of their experts or the reports/studies

\footnotetext{
- Junior Lecturer, "Ștefan cel Mare" University of Suceava, Romania, Faculty of History and Geography, Department of Humanities and Social-Political Sciences, e-mail: raiu.sergiu@yahoo.com
} 
conducted over time on the subject in question, or through advocacy, when NGOs directly aim to change a public policy or law and make intense efforts in this regard with the competent authorities. However, influencing public policies is not a current and constant concern of NGOs, but rather emerges as an instant reaction to various community issues. A recent study (FDSC, 2017) shows that only 30\% of NGOs have as main activities disseminating information, awareness, research, advocacy and monitoring public policies. The success rate of the proposals submitted is $15 \%$ in the case of NGOs, which state that, to some extent, they have succeeded in influencing the decision in the targeted direction. Regarding the methods used by NGOs to influence policies, $21 \%$ use requests for public information and $13 \%$ written requests for organizing public debates, namely the structural tools in advocacy processes provided by laws 544/2001 and 52/2003. Regarding the methods of transmitting their messages about public policies, the most commonly used ways are communication and mobilization of members, along with press releases. At the opposite pole are the participation in the sittings of the Parliament and the organization of demonstrations (FDSC, 2017: 109-110).

The article describes the approach of the Help Autism Association to develop and propose a public policy in the field of autism in order to influence the decision makers to improve the system of providing services for people with autism spectrum disorders and their families. The described stages are part of a research-intervention project namely "Increasing the involvement of NGOs and social partners in promoting alternative public policies for children with ASD (ONGPP)" implemented by the Help Autism Association and can be considered an example of good practice on how to advocate for other NGOs from various fields.

The problem of autism is a major one, as are many other health problems. There is an alarming incidence of autism worldwide, 1 in 59 children are diagnosed with autism spectrum disorder, according to the US Centers for Disease Control and Prevention (CDC) and 1 in 160 children, according to the World Health Organization. In Romania, the lack of a real specialized integrated system of services at national level and the insufficiency of recovery and rehabilitation services (in 2019 there were 38 state centers in all 41 counties and the Capital) were the premises from which the alternative policy proposal started and was designed to find solutions for the growing need of developing and normalizing Integrated Specialized Services (ISS) for people with autism.

In 2018, at national level, 11,214 children with ASD were registered by the National Authority for the Protection of Children's Rights and Adoption (ANPDCA) and approximately 1,000 children are diagnosed annually with ASD in Romania, according to the National Institute of Public Health. The Romanian society began to turn more attention to the issue of autism, when an inappropriate statement of the Prime Minister of Romania and later by the Minister of Health at that time (2018-2019), sparked a wave of outrage among parents who have children who suffer from this mental disorder and who have felt offended. One of the largest NGOs in the field of autism has notified the Government and the Council for Combating Discrimination (CNCD). At the same time, 
CNCD, 2018 notified itself, analyzed the statements and the behavior from the perspective of committing a possible act of discrimination, by violating the right to human dignity of people with autism. The Prime Minister escaped sanctions following the voting of CNCD members, and later publicly apologized. Shortly after the incident, the President of Romania, Mr. Klaus Johannis, used the word "autistic" in a demeaning sense, indirectly harming the group of parents/relatives of people with autism in Romania.

A favourable context occurred in the fall of 2018, when the Prime Minister of Romania set up a committee whose main objective was to develop a National Plan for Autism for the period 2020-2022, the first plan developed by authorities for people with autism in Romania (by comparison, France has developed the 4th National Plan on Autism) in order to improve the living conditions of people with autism spectrum disorders, the national plan for autism will be approved by Government decision, at the proposal of the Ministry of Health. The Committee for the development of the National Plan for Autism in the period 2020 - 2022 was established by a decision of the Prime Minister, published in 2018 in the Official Gazette. According to the Prime Minister's decision, the Committee is an inter-ministerial body, with an advisory role, without legal personality, consisting of the General Secretariat of the Government (SGG), the Prime Minister's Office, the Ministry of Health, the Ministry of Education, the Ministry of Labor and Social Justice, the Ministry of Regional Development and Public Administration, the Ministry of Finance, the National Center for Mental Health, the National Authority for People with Disabilities and the National Authority for the Protection of the Rights of the Child and Adoption.

Another favorable context for improving the service delivery system for people with autism was April 2, 2019, when every year worldwide is marked World Autism Awareness Day. Taking into consideration that the support and social integration of people with autism spectrum disorders require not only medical facilities or services related to this, but also social and educational services, on April 2, 2019 was signed by the Ministry of Health, Ministry of Public Finance, Ministry of National Education and CNAS a collaboration protocol on the implementation of measures necessary to increase the access of people diagnosed with autism spectrum disorders to integrated health, social and education services. The objectives of the protocol are to create an exclusive subprogram for people with ASD within the National Mental Health Program, to organize and conduct a training program for teachers, school counselors and social workers. The training of families of children diagnosed with autism spectrum disorders will also be considered. These objectives will run from the second semester of 2019, for a period of 3 years.

\section{Methods}

In the elaboration of the alternative public policy proposal, in the field of providing personalized integrated specialized services (social, educational, health), several stages were completed, which taken together led to the development and promotion of the 
public policy. Below are described the stages of the approach to the realization of the public policy proposal:

Stage 1 - Establishing an associative structure. Involvement in associative structures can be a useful working process in influencing public policies. NGOs are among the organizations most connected to everyday reality and are sometimes best able to provide solutions to the problems that the community are facing. Many NGOs have their own experts, who can share their knowledge in the public interest whenever needed or when it comes to considering the best alternative solutions recommended by public policy proposals. Of maximum importance is the collaboration between NGOs and institutions and carrying out actions in partnership, but in Romania, these collaborationspartnerships are still in an emergent phase. In Romania, 28\% of organizations are members of national federations (up from 17.7\% in 2010), and the rate of membership in networks/informal national coalitions is $25 \%$. At European level, $12 \%$ of organizations are members of federations. 14\% of Romanian NGOs are involved in informal European structures, and 18\% were involved in advocacy actions at European level in 2015, up from 8.4\% in 2009 (FDSC, 2017: 112).

One of the specific objectives of the project was to develop at national level a network of NGOs in autism in order to formulate and promote alternative proposals to existing public policies to support children with ASD and their families. Thus, based on collaboration agreements, 64 NGOs were initially co-opted into the RO ASD Network, the network of NGOs in autism, established within the project. Subsequently, during the implementation of the project, their number reached $80 \mathrm{NGOs,} \mathrm{thus} \mathrm{covering}$ organizations across the country and being the largest network of NGOs in autism.

Help Autism Association, implementer of the project and one of the largest NGOs in the field, organized a launch conference of the RO ASD Network in Bucharest, in 2019, which was attended by 46 specialists, practitioners and presidents of NGOs / institutions in the field. Of these, 37 were representatives of NGOs and 9 representatives of institutions. Among the institutions, there were present the National Authority for the Protection of the Rights of the Child and Adoption (ANPDCA), the General Secretariat of the Government (SGG), the Ministry of National Education (MEN), Social Assistance Directorates (DASs), while from the non-governmental sector, representatives from 23 autism NGOs from Argeș, Bihor, Botoșani, Brașov, Bucharest, Constanța, Suceava, Târgu Mureș, Timișoara and Tulcea were present.

The RO TSA Network is the largest associative structure, without legal personality that currently functions as an informal, noninstitutionalized union, open to new members, created in order to strengthen and increase the capacity of the network of NGOs in autism. In Romania, there is another coalition in this field, namely the Federation for Rights and Resources for People with Autism Spectrum Disorders (FEDRA, 2019) which aims to create and maintain an appropriate environment to stimulate and support people with autism spectrum disorders and their families. The Board of Directors of the RO TSA Network was democratically elected by online vote and is composed of a 
representative from each of the 8 development regions of Romania and a president, represented by the president of the project implementing association. Once the associative structure was created, all steps to report irregularities in the system of providing services for people with ASD, the observation/violation of their rights, as well as concrete proposals for solutions are made in the name and with the consent of all network members.

Stage 2 - Carrying out qualitative research. The objective of the qualitative research was to analyze and to understand the practices and needs of the service delivery system for people with autism, from the point of view of the main actors - beneficiaries (parents and children), associations that provide therapy services (NGO sector) and public institutions involved in diagnosis, recovery, integration. Along with contacting the institutions and NGOs to co-opt the members in the target group of the project, interviews were also carried out with those who were to enter the project as beneficiaries. Data collection was done through in-depth interviews, by developing 3 interview guides (specialists from institutions, NGO practitioners and parents of children with ASD), and the data were collected from 8 development regions by 2 experts in public policies between August and September 2018. Each of these 3 guides contained between 25 and 40 open-ended questions on issues related to the practices of diagnosis, recovery and integration of people with ASD. Topics related to the specific needs of the system such as specialized staff, training, accreditation, work experience in advocacy networks, the relationship between the state and the private sector in the field of health, social and educational services were also addressed. The initiative aimed to obtain as much diversity as possible of practices, opinions, ways of relating to the intervention system by including in the lists of respondents specialists in education, health, social assistance, representatives of local public authorities, management and implementation staff. In total 134 interviews were collected through electronic communication methods (e-mail or telephone), but most of the interviews were conducted face-to-face by moving experts to the headquarters of institutions and associations. Interviews with parents/relatives of children with ASD were also conducted at NGOs headquarters. Following the interviews, a qualitative research report was made and can be found on the Project Forum (Help Autism Association, 2019).

Stage 3 - Regional debates with specialists from institutions and NGOs. In order to formulate alternative public policies, within the project 8 regional consultations of focus-group type were organized, one in each of the 8 development regions of Romania. The purpose of these consultations was to identify existing problems and formulate solutions because they can be developed into alternative public policy proposals. The consultations took place during one day, in Brașov (Center Region), Cluj (North West Region), Bucharest (South Muntenia Region and Bucharest-Ilfov Region), Constanța (South East Region), Timișoara (West Region), Iași (North East Region) and Craiova (South West Oltenia Region). In total, 139 representatives of the target group of the project were consulted in the field of providing specialized services for children with 
autism spectrum disorders and their families, as well as representatives of institutions such as General Directorates of Social Assistance and Child Protection (DGASPCs), educational institutions of inclusive education (CSSEI), county centers of resources and educational assistance (CJRAE), directions of social assistance (DASs) within the town halls, Mental Health Centers, (SCMs), county school inspectorates, (ISJs), individual medical offices (CIMs) and individual psychological offices (CIPs). Through these focus groups an attempt was made to obtain information, identify needs and solutions in a way that is as balanced and close to reality as possible, both from the perspective of nongovernmental and institutional field.

Stage 4 - Participation in consultations on the implementation of the National Plan for Autism 2020-2022. The Help Autism Association as a representative of the RO TSA Network, along with 3 other NGOs in the field, were also part of the Committee set up within the Government for the elaboration of the National Plan on Autism 2020-2022. Help Autism provided the inter-ministerial committee with data, reports, studies on autism issues, at the request of the General Secretariat of the Government. Also, through its own approach, the association consulted both specialists from institutions and NGOs, as well as parents/relatives of people with autism from NGOs members of the RO TSA Network. The method of collecting opinions was the sociological survey based on a selfadministered online questionnaire (Google Forms) in order to identify the needs and to propose solutions in the field of providing integrated specialized services for people with ASD. We collected 47 responses from specialists from institutions, members of the target group of the project and practitioners from NGOs and 303 responses from relatives/guardians of people with ASD. The centralized and synthesized responses were submitted to the Committee for the elaboration of the National Plan for Autism 20202022 by drawing up a Report on Needs Analysis and Proposed Solutions in the Field of Providing Integrated Specialized Services for People with Autism Spectrum Disorders (Help Autism Association, 2019).

Stage 5 - Analysis of the Impact of Legislative Regulations in the field. During February-March 2019, 8 working meetings took place in all 8 development regions of Romania. The regional consultations took place during a day in the cities of Cluj, Brașov, Bucharest, Constanța, Timișoara, Iași and Craiova. These meetings were attended by 151 specialists, of which 90 representatives of public institutions (management and executive staff) and 61 representatives of NGOs who were informed about the method of Assessing the Impact of Legislative Regulation and proposed concrete solutions to identified problems in the practice of providing services for people with ASD and their families.

Stage 6 - Training the network members on the advocacy process. 8 training sessions in the field of advocacy were organized with representatives from NGOs in all 8 development regions in Romania. Advocacy training sessions took place between April and July 2019, in each region over 2 days, with a duration of 16 hours of training, as follows: Iași (14 participants), Timișoara (11 participants), Bucharest (27 participants in 4 days), Brașov (10 participants), Craiova (9 participants), Cluj (14 participants), 
Constanța (11 participants). A total of 96 representatives of the non-governmental sector were trained in the advocacy process in all 8 training sessions. The Advocacy Knowledge and Skills Development Program has helped increase the target group's ability to promote, both during the project implementation period and after its completion, the social cause of children with ASD and their families and to rally citizens for solving the problem and for actively participating in the change of public policies, turning the activity of influencing public policies in the field into a constant, current concern of those interested. At the end of each advocacy training session, the members of the NGOs were presented with the horizontal principles of EU-funded projects in the Administrative Capacity Operational Program (AOCP): equal opportunities and gender equality, nondiscrimination and sustainable development in the context of integrated service delivery for people with ASD.

Stage 7 - Consultation of decision makers in inter-ministerial working groups. 3 working meetings were organized with an Inter-ministerial Group, based on personalized Invitations sent by e-mail to the representatives of the institutions and to the 8 members of the RO TSA College by ANPDCA and the project implementation team.

The purpose of these working meetings with an inter-ministerial group was to identify the topic of public policy to be written and promoted in the field of managing the situation of children with autism spectrum disorders. The 3 working meetings with the inter-ministerial group took place on a monthly basis. The inter-ministerial working groups included the consultation of 31 representatives from 17 non-governmental organizations providing services to people with ASD and 18 representatives of institutions from the Ministry of Health $(\mathrm{MoH})$, the Ministry of National Education (MEN), the Ministry of Public Finance (MFP), the Ministry of Labor and Social Justice (MMJS) through the National Authority for the Protection of the Rights of the Child and Adoption (ANPDCA); National Health Insurance House (CNAS); National Center for Mental Health and Anti-Drug Control (CNSMLA); "Titan" Psychiatric Hospital Bucharest, National Qualifications Authority (ANC), Bucharest Center for Educational Resources and Assistance (CMBRAE), Complex Assessment Service (SEC) within the DGASPCs Sector 3 and Sector 6 and teachers from the University of Bucharest.

Stage 8 - Carrying out the advocacy campaign. Public consultation on the public policy proposal. The draft alternative public policy resulting from consultations with the inter-ministerial working group was posted for 30 days on the website of the initiating association, on the project forum and, using a link, on the website of the partner institution, ANPDCA. Thus, the announcement was sent to potential decision makers, and the approach invited citizens to express their opinion in writing, sending proposals/suggestions to the e-mail address of an expert in the project. The opinions received were systematized and conclusions and recommendations were drawn for policy makers.

Stage 9 - Conducting a public debate during a day. A public consultation took place in Bucharest, during a day, at the headquarters of the central authority with competences 
in the field, ANPDCA. The announcement of the public consultation was made online, on the website of the central public authority, on the Project Forum and on the website of the initiating association. Following the public consultation, a document was prepared to record the conclusions of the discussions, which was made available to the decisionmakers. A map of the interested participants was also elaborated in order to position in a chart those who can help or those who can hinder the approach to achieve the objectives (supporters, allies, opponents).

Stage 10 - Organizing a round table to sign an agreement in principle. The project implementation team submitted on the formalized channel, officially, to the attention of the central public authority responsible in the field, the alternative proposals to the current public policies. The implementation team took steps to organize a round table attended by policy makers in the field to sign an agreement in principle stating that they will further promote to existing public policies the alternatives proposed by the project. The conclusions were discussed following the analysis of the impact of legislative regulations, consultations with decision-makers in inter-ministerial working groups and following the advocacy campaign through public consultation and debate. The project team received a positive response from the central public authority, ANPDCA, through a written address, assumed by the legal representative of the institution by signature.

\section{Results}

The public policy proposal was created through an extensive consultative process to which representatives of 80 NGOs and 64 specialists from institutions (DGASPCs, CJRAE / CMBRAE, ISJs, School Education Centers) contributed. Inclusive (CESE), DAS, Mental Health Centers (SCM), as well as specialists from central institutions, ministries and public authorities.

Following the consultations of those involved in autism (parents/relatives, specialists of institutions and NGOs with responsibilities in the field), both through interviews and questionnaires applied, and following discussions in focus groups, the following problems in the provision of services for people with autism emerged: the lack of a framework for cooperation between all factors involved in managing the situation of children with autism spectrum disorders in order to monitor the stages of coping with this situation, late diagnosis of children and lack of early intervention, enrollment in a nationalized centralized record of ASD cases, the shortage of specialists in the field (both state and private), but also the insufficient theoretical and practical training of specialists, poorly developed services and difficult access of children to them ( difficult route for parents and the need to guide them in this route and often even providing counseling on accepting the situation of raising the child with ASD), the difficult integration of children with ASD in schools and underdeveloped services for adults over 18 with ASD.

In the case of children with autism spectrum disorders, early diagnosis and intervention are essential in their total/partial recovery. Therefore, late diagnosis and lack of early 


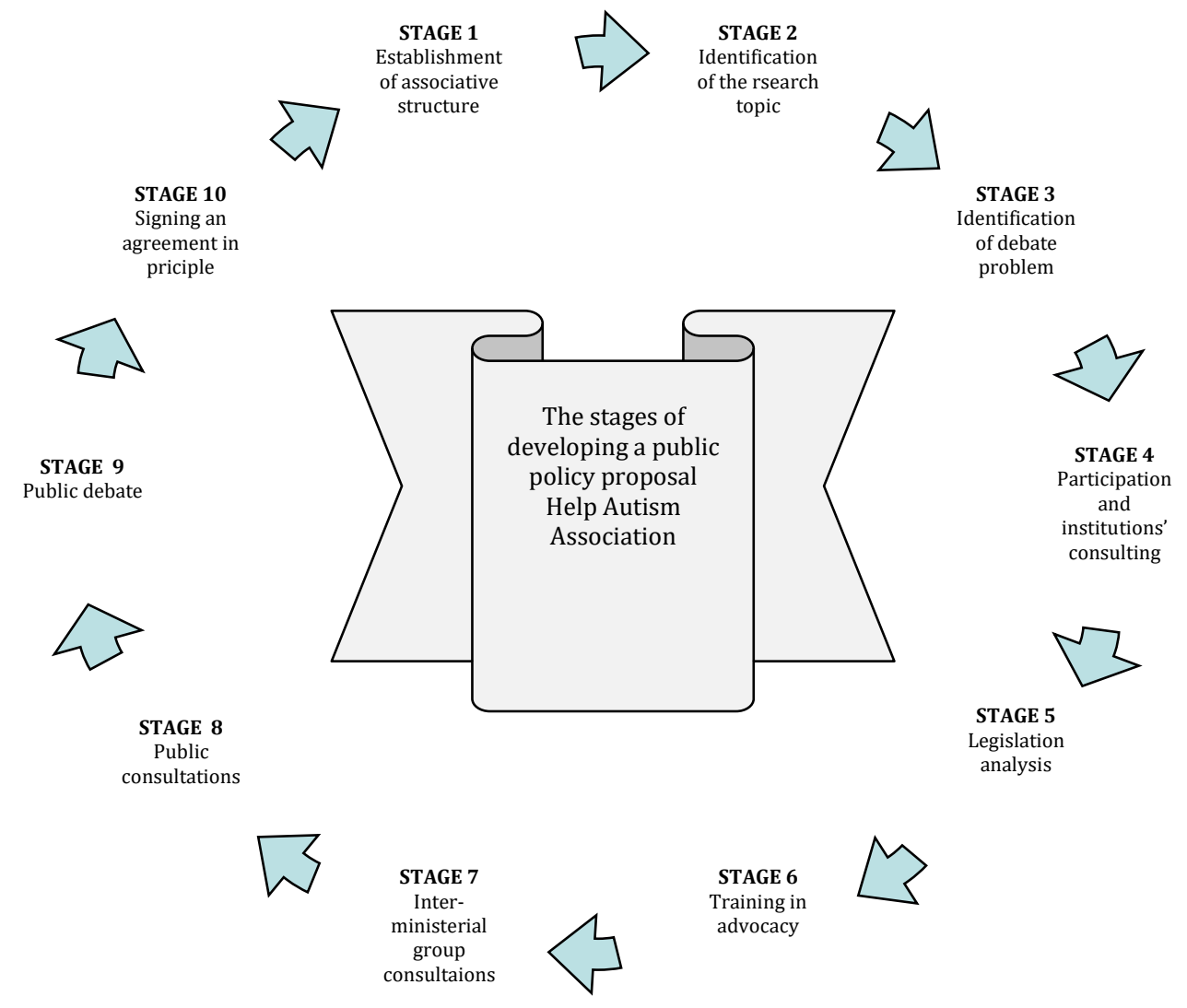

Figure 1. The stages of developing a public policy proposal

intervention have negative effects on the chances of recovery of children with autism. Gazibar, Petrescu, Stănilă, (2018) show a trend of increasing the access of the rural population to primary health services by the fact that the everyday presence of the general practitioners (family doctors) increased in rural areas from $11.5 \%$ in 2012 to $28.4 \%$ in 2018 . However, $10 \%$ of the respondents of the study (in the case of households where there are children under 5 years) still state that they have not benefited from a consultation of the general practitioner in the last year, the percentage increasing greatly compared to 2016 when only 3, 4\% stated that these children were not consulted by the family doctor. In the case of people with ASD, the family doctor has a key role because he is the first medical specialist that has access to the child in the first months and he can detect autism early. In the last 10 years, the number of newly detected cases of people with ASD in family doctors' offices has increased from year to year, from 361 cases in 2008 to 1,147 in 2017 (Figure 2). 


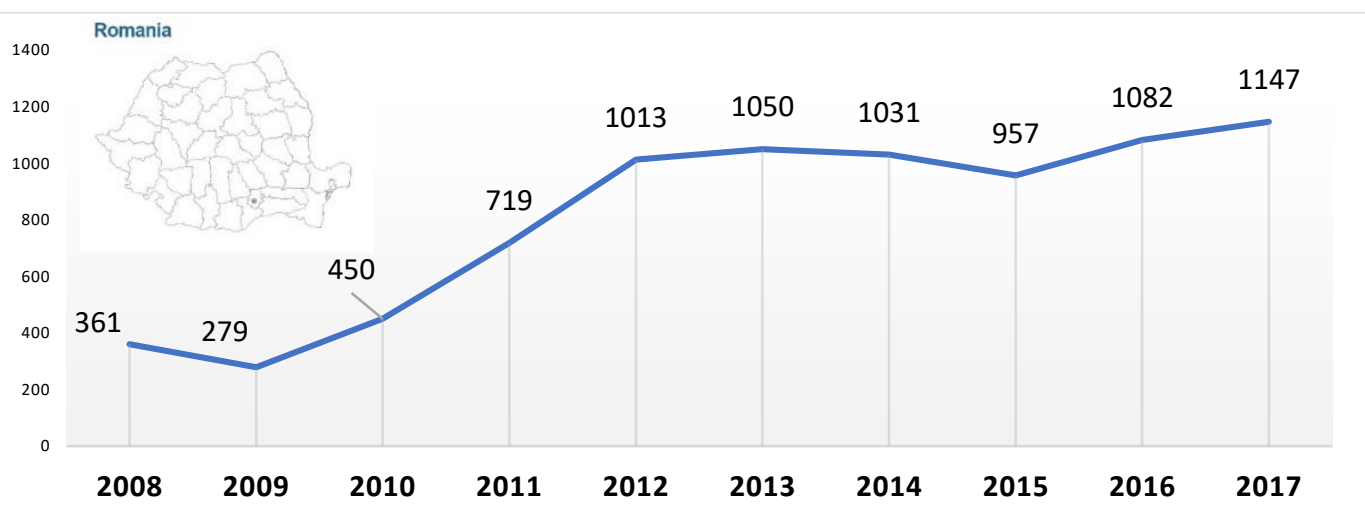

* According to ICD 10 - Other disorders of psychological development and without specification (CODE F83, F84, F88, F89) Source: National Institute of Public Health, family doctors' offices

Figure 2. New cases of autism spectrum disorders, between 2008-2017

In Romania, in 2019 there was no clear, centralized record of children with ASD, the only existing data were statistical data held by various interested institutions (INSP, ANPDCA, MEN), disparate, non-unitary, related to the services they provide. In 2019 there was not an established coherent framework for reporting and registration of children/people with ASD, there were no real databases at county or national level, there were only partial data in the statistics made by DGASPCs, but they included only cases of children registered for the issuance of the certificate of disability, as well as children who benefited from recovery therapies offered by DGASPCs. Existing data often do not distinguish between children with ASD and those with other types of developmental disorders. The effect of this state of affairs is the lack of accurate, public data on the number of people with ASD in Romania. This leads to difficulties in setting up evidencebased public policies on the need for ASD interventions and in assessing the need to fund measures to recover children with ASD.

Following the steps taken by the RO TSA Network, data were obtained from ANPDCA and the National Institute of Public Health (INSP). According to statistical data provided by ANPDCA, in 2019 there was registered a number of 11,214 children with ASD out of which 2,856 were female and 8,385 male. We specify that these data refer only to children with ASD (children with disabilities) who are in the records of the General Directorates of Social Assistance and Child Protection (DGASPC) at the county level. NGOs talk about a double number of children with ASD because there are cases where parents do not register their children with DGASPCs which can issue a certificate of disability for fear that the child might be discriminated in the future. From the perspective of the age groups, the situation of the data provided by ANPDCA in 2019 showed that in the age group 1-3 years there are 474 children, in the age group 3-6 years there are 2,415 children, and in the age group 6-18 years there are 8,352 children. 
Table 1. Distribution by gender and age group

\begin{tabular}{|c|c|c|c|c|l|l|}
\hline Gender & \multicolumn{3}{|c|}{ Female } & \multicolumn{3}{c|}{ Male } \\
\hline Age & $\begin{array}{l}\mathbf{1 - 3} \\
\text { years }\end{array}$ & $\begin{array}{l}\mathbf{3 - 6} \\
\text { years }\end{array}$ & $\begin{array}{l}\mathbf{6 - 1 8} \\
\text { years }\end{array}$ & $\begin{array}{l}\mathbf{1 - 3} \\
\text { years }\end{array}$ & $\begin{array}{l}\mathbf{3 - 6} \\
\text { years }\end{array}$ & $\begin{array}{l}\mathbf{6 - 1 8} \\
\text { years }\end{array}$ \\
\hline No. & 132 & 632 & 2092 & 342 & 1783 & 6260 \\
\hline Total & \multicolumn{3}{|c|}{2856} & \multicolumn{3}{c|}{8385} \\
\hline
\end{tabular}

Source: Data received by project members from ANPDCA, 2019

From the perspective of residence of children with ASD, from the data provided by ANPDCA, it results that from the total number of children with ASD in evidence, in 2019, 6,709 children came from urban areas, and 4,532 children with ASD lived in rural areas.

Table 2. Distribution by residence

\begin{tabular}{|c|c|l|c|c|c|c|}
\hline Residence & \multicolumn{3}{|c|}{ Urban } & \multicolumn{3}{c|}{ Rural } \\
\hline Age & $\begin{array}{l}\mathbf{1 - 3} \\
\text { years }\end{array}$ & $\begin{array}{l}\mathbf{3 - 6} \\
\text { years }\end{array}$ & $\begin{array}{l}\mathbf{6 - 1 8} \\
\text { years }\end{array}$ & $\begin{array}{l}\mathbf{1 - 3} \\
\text { years }\end{array}$ & $\begin{array}{l}\mathbf{3 - 6} \\
\text { years }\end{array}$ & $\begin{array}{l}\mathbf{6 - 1 8} \\
\text { years }\end{array}$ \\
\hline No & 316 & 1527 & 4866 & 158 & 888 & 3486 \\
\hline Total & \multicolumn{3}{|c|}{6709} & \multicolumn{3}{c|}{4532} \\
\hline
\end{tabular}

Source: Data received by project members from ANPDCA, 2019

From the perspective of the social environment in which children with ASD live (with their families or in the special protection system), the ANPDCA data show the following:

Table 3. The social situation of children with ASD in the records of the institutions

\begin{tabular}{|c|c|c|c|c|c|c|c|c|}
\hline \multicolumn{3}{|c|}{$\begin{array}{c}\text { Number of children with } \\
\text { certification of disability }\end{array}$} & \multicolumn{3}{c|}{$\begin{array}{c}\text { Number of children in } \\
\text { families }\end{array}$} & \multicolumn{3}{c|}{$\begin{array}{c}\text { Number of children in social } \\
\text { protection system }\end{array}$} \\
\hline $\begin{array}{c}1-3 \\
\text { years }\end{array}$ & $\begin{array}{c}3-6 \\
\text { years }\end{array}$ & $\begin{array}{c}6-18 \\
\text { years }\end{array}$ & $\begin{array}{c}1-3 \\
\text { years }\end{array}$ & $\begin{array}{c}3-6 \\
\text { years }\end{array}$ & $\begin{array}{c}6-18 \\
\text { years }\end{array}$ & $1-3$ years & $\begin{array}{c}3-6 \\
\text { years }\end{array}$ & $6-18$ years \\
\hline 470 & 2401 & 8343 & 459 & 2314 & 7743 & 15 & 100 & 608 \\
\hline
\end{tabular}

Source: Data received by project members from ANPDCA, 2019

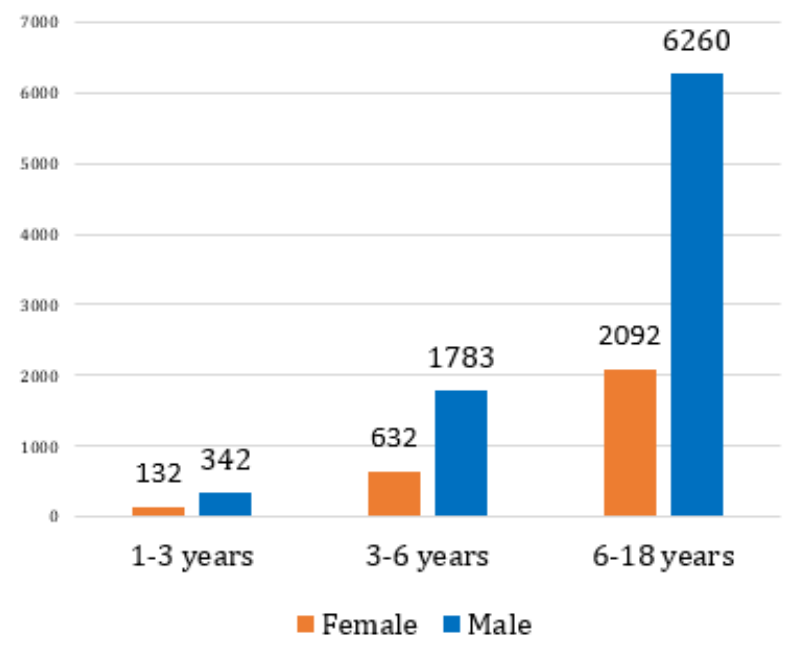

Source: Data received by project members from ANPDCA, 2019

Figure 3. Number of children with ASD by age and gender 


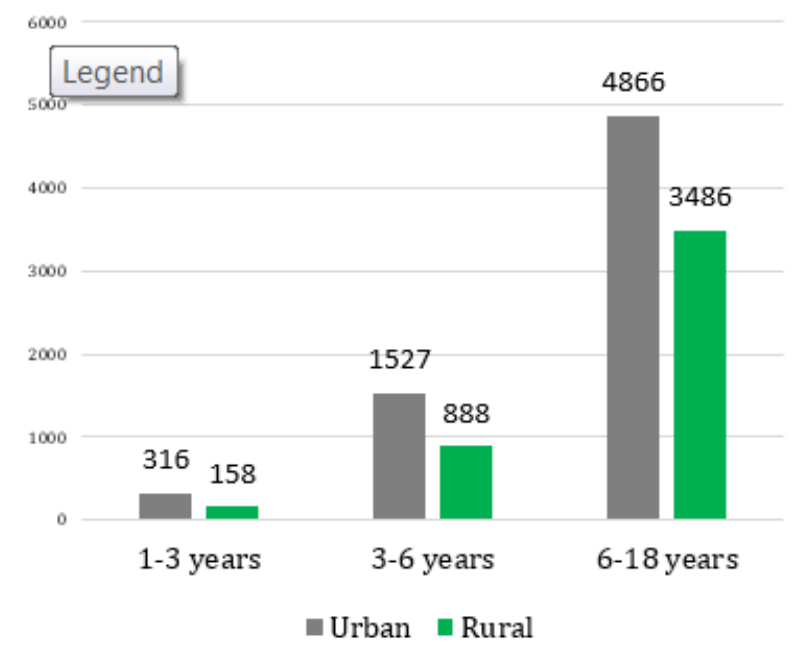

Source: Data received by project members from ANPDCA, 2019

Figure 4. Number of children with ASD by age group and background

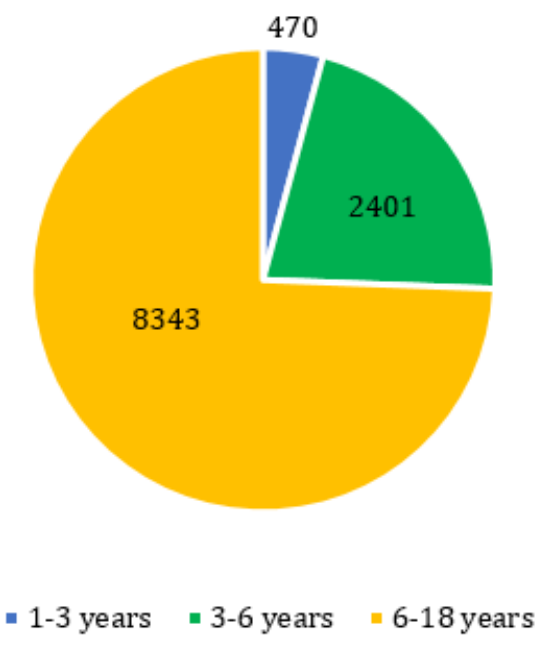

Source: Data received by project members from ANPDCA, 2019

Figure 5: Number of children with certificate of disability

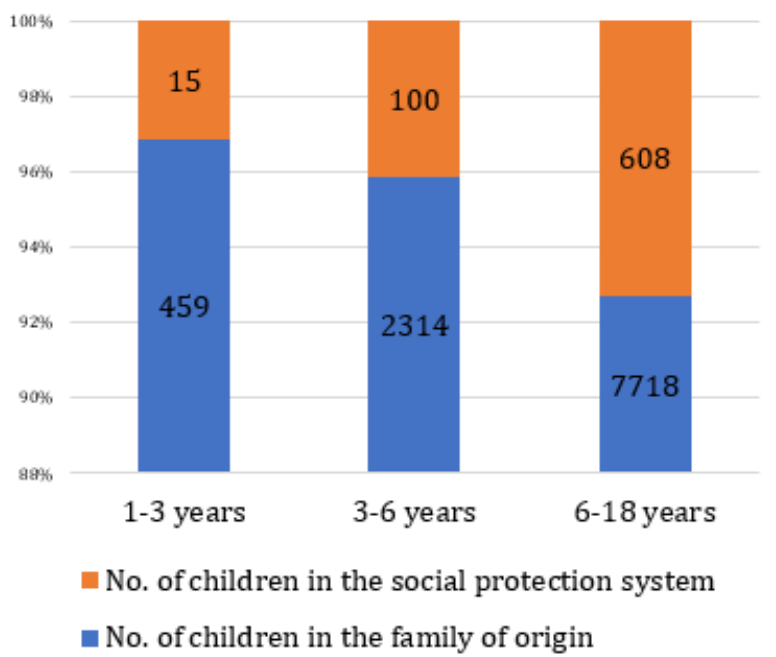

Source: Data received by project members from ANPDCA, 2019

Figure 6. Number of children with ASD depending on the family environment 
According to the data obtained from the INSP records, data referring to new cases detected by other disorders of psychological development and without specification (CODE ICD 10 - F83, F84, F88, F89), data reported by family doctors, in the last 10 years, a number of 8,089 new cases of children with ASD were identified in the period 20082017, distributed as follows:

Table 4. Number of annual cases of ASD by gender and area of residence

\begin{tabular}{|c|c|c|c|c|c|}
\hline \multirow[b]{2}{*}{ Year } & \multirow{2}{*}{$\begin{array}{c}\text { New } \\
\text { ASD } \\
\text { cases }\end{array}$} & \multicolumn{2}{|c|}{ Gender } & \multicolumn{2}{|c|}{ Residence } \\
\hline & & Male & Female & Urban & Rural \\
\hline 2008 & 361 & 186 & 175 & 252 & 109 \\
\hline 2009 & 279 & 188 & 91 & 193 & 86 \\
\hline 2010 & 450 & 267 & 183 & 312 & 138 \\
\hline 2011 & 719 & 427 & 292 & 484 & 235 \\
\hline 2012 & 1013 & 607 & 406 & 669 & 344 \\
\hline 2013 & 1050 & 635 & 415 & 678 & 372 \\
\hline 2014 & 1031 & 632 & 399 & 627 & 404 \\
\hline 2015 & 957 & 614 & 343 & 569 & 388 \\
\hline 2016 & 1082 & 708 & 374 & 607 & 475 \\
\hline 2017 & 1147 & 763 & 384 & 690 & 457 \\
\hline
\end{tabular}

Source: National Institute of Public Health, 2019

The data from The National Institute of Public Health (INSP) are divided by age groups, but the intervals of the age groups are different from the age ranges registered by ANPDCA. Thus, in the period 2008-2012, the age groups used in the INSP statistics were: 0 -1 years and 1-14 years. Starting with 2013, the age groups used in INSP statistics are: 0-4 years, 5-9 years, 10-14 years and 15-19 years.

An analysis of the current legislative framework found that there are stipulations in providing integrated specialized health, education and social services aimed at early identification, treatment, recovery and improvement of the quality of life and social functioning of people diagnosed with autism spectrum disorders and with associated mental health disorders. The normative act that defines what are the integrated specialized services addressed to people with ASD is the Autism Law which at art. 2 mentions that: "the integrated specialized health, education and social services are: early active detection, psychiatric clinical diagnosis and psychological clinical evaluation, psychopharmacological treatment, early specialized interventions, cognitive-behavioral psychotherapy, psychological counseling of parents and family, as well as educational services for children with autism spectrum disorders and associated mental health disorders". The autism law 151/2010 used the term "integrated services", but until 2016, when the law enforcement rules were published, it was not known what these integrated services contained.

Thus, the medical services are provided by professionals accredited by the Romanian Medical College within the public or private health units, according to the legislation in force (art. 1 paragraph (1) letter f) point 1 of the Methodological Norms), health services related to the medical act are provided "by professionals accredited by the Romanian 
College of Psychologists, according to the legal stipulations in force in public or private institutions" (art. 1 paragraph (1) letter f) point 2 of the Methodological Norms ), social services "are provided by accredited public and private social service providers, according to the legislation in force" (art. 1 paragraph (1) letter f) point 3 of the Methodological Norms), and educational services "are provided by teachers from public or private institutions authorized/accredited according to the National Education Law no. 1/2011, with subsequent amendments and completions " (art. 1 paragraph (1) letter f) point 4.1 of the Methodological Norms). Art. 7 para. (1) of the Methodological Norms stipulates that social services addressed to the person with ASD "have a proactive character and presuppose an integrated approach to his needs, taking into account the socio-economic situation of the person/parents/legal representative, health status, level of education and the social living environment and the recommendations contained in the Plan for the Recovery of the Child with Disabilities or, as the case may be, in the Individual Rehabilitation and Social Integration Program, in the case of the adult with ASD, respectively the Individual Services Plan". Para. (2) of the same article stipulates that "The Plan for the Recovery of the Child with ASD includes the objectives set by the multidisciplinary team to enable and or rehabilitate the child in all areas of interest, therapies recommended for this purpose, concrete ways to perform specific activities of habilitation and/or rehabilitation achievable in the specialized services closest to the child". Para. (9) stipulates that: "for the benefit of the person with ASD, social services may be organized and provided in an integrated system with employment, health, education services, as well as other social services of general interest, for a coherent, unitary and efficient intervention".

Although Art. 5, para. 5 of Law 151/2010 stipulates that the Ministry of Health, the Ministry of Labor and Social Justice and the Ministry of National Education elaborate, in consultation with the Romanian Medical College and the Romanian College of Psychologists, the standards for integrated specialized health, education and social services for people with autism spectrum disorders and associated mental health disorders, which were supposed to be included in the methodological rules for the application of Law $151 / 2010$, they do not exist even 9 years after the issuance of the law. The methodological norms for the application of Law no. 151/2010 were approved in 2016 by Joint Order no. 968 / 5194 / 714 / 1945 issued by the Ministry of Health, the Ministry of National Education and Scientific Research, the National Health Insurance House and the Ministry of Labor, Family, Social Protection and the Elderly, but they do not include a standard for integrated health, educational and social services for people with autism spectrum disorders.

Most NGOs in the field offer recovery services (therapies), but in the absence of official standards appropriate to the types of services they provide, children with autism spectrum disorders cannot be guaranteed quality services, and the risks that these children and young people with ASD not to receive integrated and personalized services (social, educational and health) and/or counseling services for their families and this to affect their chances of development are relatively high and should not be neglected. 
Specific training standards in psychotherapy for people with autism spectrum disorders and associated mental disorders should be found in the methodological rules for the application of Law 151/2010. According to Art. 8, Paragraph 2 letters a) and b) specific training standards in psychotherapy for people with ASD and associated mental disorders include standards of continuous training, short-term specialization in autism spectrum disorders and associated mental disorders for the professionals certified in cognitive-behavioral psychotherapy and training standards in interventions specialized in autism spectrum disorders and associated mental disorders for the specialized multidisciplinary team provided in art. 3. According to Art. 8, para. 1 of law 151/2010 these should be carried out by the Romanian Medical College, the Romanian College of Psychologists and the Romanian Federation of Psychotherapy. Integrated specialized services are provided by professionals with competence established by the Romanian Medical College or by the Romanian College of Psychologists (Law 151/2010, art. 5, paragraph 1). Integrated specialized services are also provided by pediatric psychiatrists and clinical psychologists (Law 151/2010, Art. 7). For more than 9 years, these specialists have not been recognized by the Romanian State, only in 2019 on the website of the Romanian College of Psychologists, 2019a were published the conditions that the psychologist must meet, cumulatively, in order to carry out professional activities of psychological intervention for children diagnosed with autism spectrum disorders. Thus, for the first time in Romania, the creation of a Register of ASD Specialists, 2019b was discussed, through which the specialists would later have direct access to the settlement of services. And Help Autism Association, through the platform www.autismconnect.ro, started several years ago, the process of centralizing the specialists from the day centers of habilitation/rehabilitation services developed by NGOs and individual psychology offices, the data collected until currently requiring special attention, especially since specialists are still not interested in making public a professional profile on such platforms, as long as there is a high demand for services. The multidisciplinary team that provides services to people with autism spectrum disorders and associated mental health disorders also includes other categories of people who have no training in psychology and we are talking here about psychopedagogues (graduates of Special Psychopedagogy), speech therapists, physiotherapists, educators and social workers. In 2019, several aspects were unknown: which institutional entity will recognize these specialists, the needed skills in working with people with ASD and how they will end up being included in such a register. DGASPC specialists have also been trained/specialized over time, both in the country and abroad, to work with people with autism. However, although there are many specialists at the level of each DGASPC with training (short or long term), in 2019, there were specialists in DGASPCs in the country who stated that they have few trainings/courses in working with people with ASD. In our country, the number of specialists certified in Applied Behavioral Analysis (ABA) therapy (one of the therapies with scientifically proven results) is much lower than necessary. In 2019, there were only 
35 ABA certified specialists in the entire country. Out of these, 21 were BCBA certified therapists and 14 were BcaBA certified.

In Romania, the National Health Insurance House (CNAS) reimburses the pediatric psychiatric medical services as well as psychological services, speech therapy, kinesiotherapy and physiotherapy, related to the medical act, necessary for patients with autism spectrum disorders, but also the services involving counseling the families which are carried out by pediatric psychiatrists. In 2019, their number was small throughout the country and nowadays this is still a problem. That is why autism NGOs propose another settlement system, directly through ASD specialists. The specialized services and interventions for people with autism spectrum disorders and other associated mental health disorders, related to the medical act are stipulated in the Framework Contract on providing medical assistance within the social health insurance system (Law 151/2010, Art. 5, paragraph 2). These services are: clinical psychological evaluation and psychodiagnosis (S1), individual psychotherapy (psychoses, obsessive-compulsive disorders, phobic disorders, anxiety disorders, dysthymia, addictions, autism spectrum disorders) (S2), clinical psychological counseling for children with autism spectrum disorders (only on the recommendation of a specialized pediatric psychiatrist) - in a psychotherapeutic method applicable to children diagnosed with autism spectrum disorders (S3), child and family psychotherapy - for children (only on the recommendation of a pediatric psychiatrist) - in a psychotherapeutic method applicable to the child diagnosed with autism spectrum disorders (S4) and services provided by the physiotherapist/physical education teacher/ kinesiotherapy (only on the recommendation of the pediatric psychiatrist) for the child diagnosed with autism spectrum disorders (S5). These are specified in Order no. 397/836/2018 regarding the approval of the Methodological Norms for the application in 2018 of the Government Decision no. 140/2018 for the approval of the service packages and of the Framework Contract that regulates the conditions for providing medical assistance, medicines and medical devices within the social health insurance system for the years 2018-2019. From $1^{\text {st }}$ July 2019, the number of sessions that pediatric psychiatrists can prescribe in one day has doubled from 180 points/day to 360 points, so, if before they could prescribe 6 sessions related to the medical act, after this date they could prescribe 12 sessions/day related to the medical act. But these medical sessions are not only given to children diagnosed with ASD but also to those with psychosis, obsessive-compulsive disorder, phobic disorders, anxiety disorders, dysthymia and/or addictions, which further increases the recovering chances of children with ASD to be small. The National Strategy for the Protection and Promotion of the Rights of the Child 2014-2020 according to General Objective 2. Respecting the rights and promoting the social inclusion of children in vulnerable situations stipulates the elimination of attitude and environment barriers for rehabilitation and social reintegration of children with disabilities by providing social, educational and health integrated services, friendly and accessible facilities for children 
with disabilities and their families. Children with disabilities should benefit from friendly and accessible services, the document states.

After the parents of children with autism spectrum disorders (ASD) completed the "Needs Identification - Questionnaire for Parents" resulted 303 responses provided by parents/relatives of children benefiting from the 80 member NGOs in the RO TSA Network. The results of the opinion poll based on an online self-administered questionnaire showed that $40 \%$ of parents/relatives say that the lack of empowerment/rehabilitation services for children with ASD is one of the biggest problems; $56 \%$ specified that for them the costs of therapeutic intervention represent a great financial effort due to the prices for the provision of therapies; $80 \%$ mentioned as a problem the path of the child with disability in order to receive diagnosis, registration in the level of disability and recovery, and $72 \%$ considered integration into the education system/society and insufficient state involvement as major problems.

One problem that blocks the direct settlement of therapy services through NGOs is that NGOs in the field are licensed on social services, because this is was officially stipulated, although they mainly offer recovery services, therapeutic services and services related to the medical act. Even so, few NGOs in the field of autism offer licensed services and this is because, according to those in the field, the licensing procedure is cumbersome and the costs for meeting the standards are huge. Although the accreditation procedure for social service providers has been simplified due to the fact that in 2019 the Government, through the Ministry of Labor and Social Justice, decided on administrative simplification for accrediting social service providers and licensing social services, in order to revise the accreditation certificate application forms and operating license, but also in the sense of removing from the list of supporting documents the administrative authorizations issued by other public authorities, many of the NGOs did not know in 2019 the new regulations. One consequence is that this prevents the direct settlement of services provided by psychologists employed in the nongovernmental sector. This is due to the fact that this licensing is done by the Ministry of Labor and not by the Ministry of Health. Of the 80 NGOs that are part of the RO TSA Network, only 30 NGOs were licensed in day centers where they provided services for people with autism (MMJS, 2019).

Another problem in the system is the lack of specialized services for empowering/rehabilitating children with ASD and associated mental health disorders and the uneven distribution of existing ones in the territory (mainly developed in urban areas). This type of integrated specialized services has not been developed in Romania, although they are described in detail in the norms of application of the autism law, these being offered within a small number of structures. In 2019 there were only 2 such centers, to our knowledge; they are also examples of good practice: the Regional Center for Educational Assistance "Speranța" Timisoara and the Center "Primăvara" in Reșița. Each of the services listed above are provided separately, by specialists accredited according 
to the specific regulations in each field, not being a unitary, standardized framework in which to provide integrated specialized services.

In Romania, autism NGOs are the most numerous of all NGOs that offer services for different social categories at risk. Most services for people with autism spectrum disorders (ASD) are provided by the non-governmental sector and not by institutions. These organizations are set up mostly by parents of children with autism, formed in associations and foundations, the phrase "behind every autism NGO is a parent" is as true as possible. Seeing that, the state does not support them very much, many parents of children with ASD have started to set up NGOs with the idea of raising funds for therapies, both for their children and for those in the community in which they live.

In 2011, the Romanian Angel Appeal Foundation (RAA) showed that most of the public services, within the DGASPCs, were dedicated to people with disabilities in general. An analysis at that time showed that out of the 41 general directorates of social assistance and child protection, only 2 had specialized services for children with autism (both being in Bucharest). In 15 DGAPSCs, services were offered to children with autism spectrum disorders, in service centers for children with disabilities or in social service centers and in 24 DGASPCs, recovery services were not offered, as they only had the possibility to make assessments of children, within the Complex Assessment Services for placing children in a degree of disability. Thus, following a project implemented by the AAR, a network of 40 care and counseling centers was set up in 2013 in partnership with local authorities (DGASPCs) and, in some cases, with local NGOs, a network for social and professional integration of people with ASD and their relatives, distributed in 35 counties of the country and in Bucharest in order to provide free services. Unfortunately, in 2019, 6 years after their establishment, there were only 17 ASD centers operating under the coordination of DGASPCs (RRA, 2013).

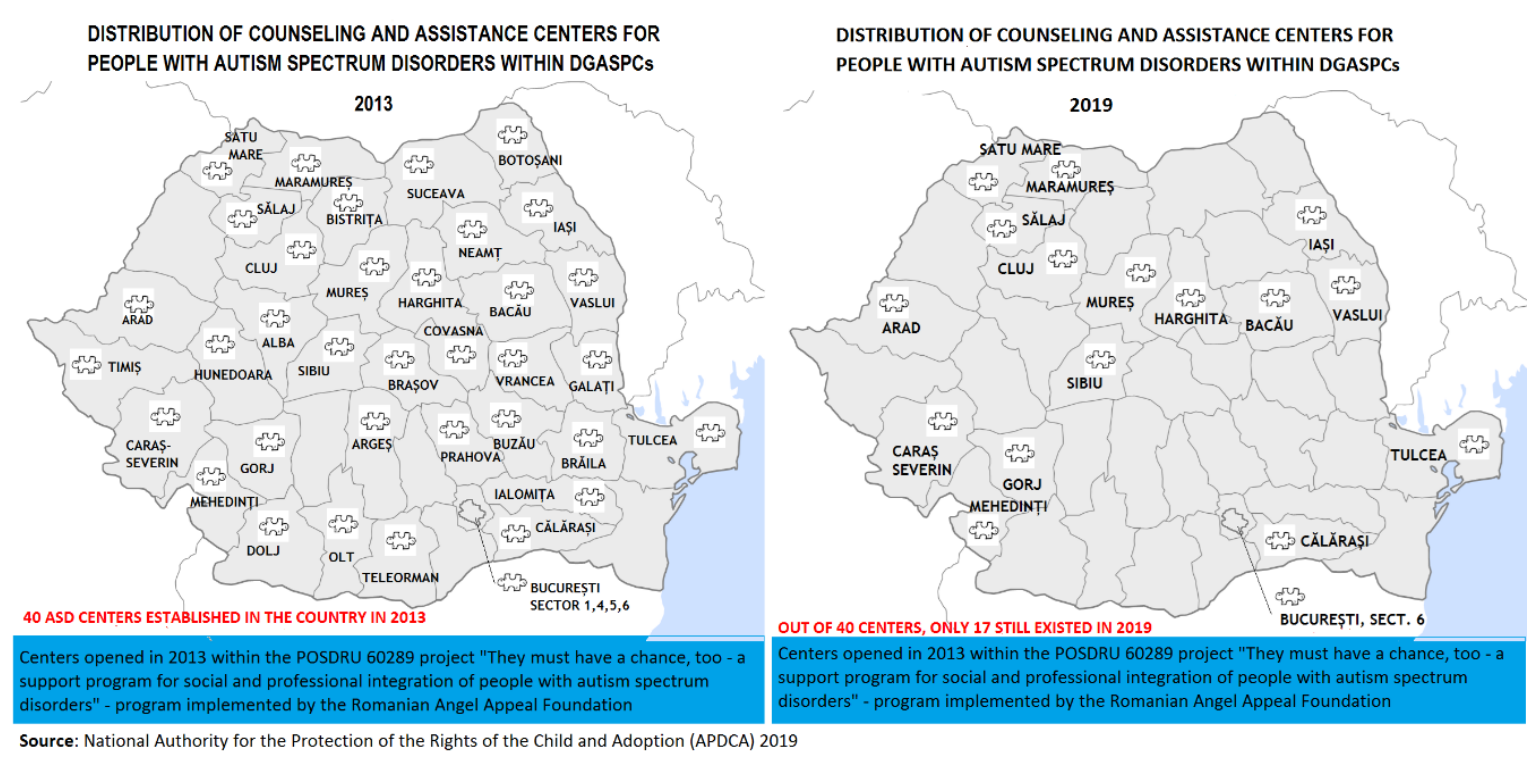

Figure 7. Distribution of counseling and assistance centers for people with autism spectrum disorders within DGASPCs (2013 versus 2019) 
Over the years, services for people with ASD have been developed, both by authorities (although the services developed within the institutions are not sufficient to cover the real need for services of empowerment/rehabilitation of children with ASD), and by private initiatives especially in big cities. In most counties, recovery services for people with ASD exist only in large cities, in county residences, while in smaller communities these services are absent, which drastically reduces the chance of children with autism living in rural areas or in small towns to have access to recovery services. Also, the services are not homogenously located, leading to difficult access for children with ASD and there are certain counties without any empowerment/rehabilitation services (for example, in 2019, Brașov and Harghita counties did not have such services). Data from 2019 showed that most DGASPCs in the country offered social services for the empowerment/rehabilitation of people with ASD and social support services for their relatives - in 38 counties, without accommodation. Support services can be: help with basic daily activities, information, personal care, social and participative integration, housing, assessment, work support services (assisted employment), ensuring access to training programs, other specialized services according to the specific and individual needs of people with ASD, according to the Norms for the application of the Autism Law 151/2010, Section 2: Social services, Art. 9, letter b. Support services without accommodation can be day centers, home care services, community services, social canteens, mobile food services, social ambulance, support services, etc., according to the Rules for the Application of the Autism Law 151/2010, Section 2: Social services, Art. 9, letter $b$.

Access is free to integrated specialized services for all people diagnosed with autism spectrum disorders and mental health disorders, but until recently children with ASD who could benefit from the services of day care centers in the state had to have a certificate of disability (Law 151/2010, art. 4, para. 2 of). At national level, the Romanian State, through DGASPCs, offers various types of social services addressed to people with ASD. These are:

- Assistance and support services in 17 counties, covering 35\% of counties nationwide;

- Personal care, recovery, empowerment and rehabilitation services (with accommodation) in 16 counties with $34 \%$ national coverage;

- Personal care, recovery, empowerment and rehabilitation services (without accommodation) in 38 counties with national coverage of $80 \%$;

- Social insertion/reinsertion services in one county - Iași;

- Training services for work and independent living in 5 counties representing 11\% of the counties at national level;

- Other types of services for people with ASD (in 4 counties). 


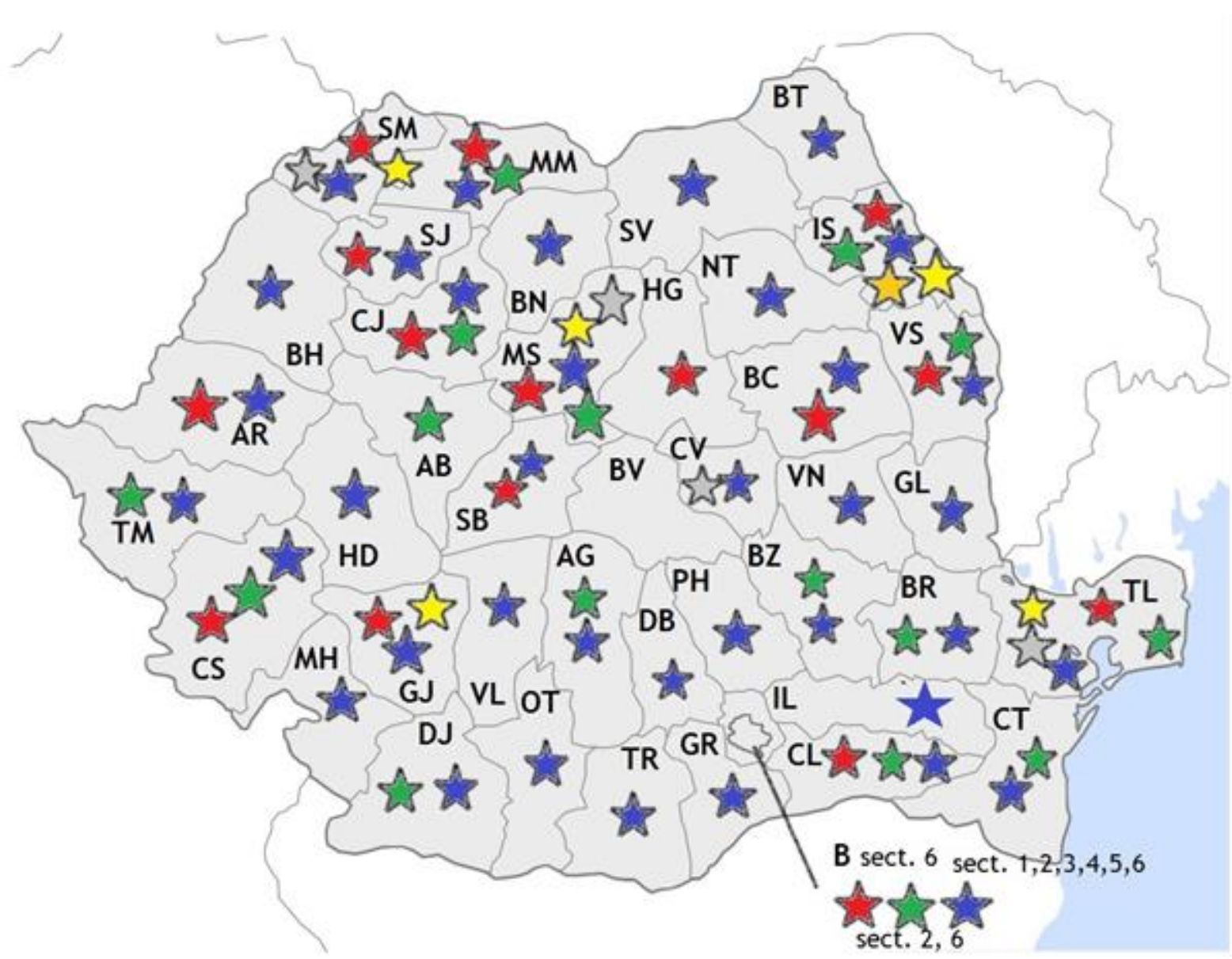

Figure 8. National distribution of social services addressed to people with autism spectrum disorders

\begin{tabular}{|l|c|c|}
\hline \multicolumn{1}{|c|}{ Types of social services for people with ASD } & $\begin{array}{c}\text { Number of } \\
\text { counties with } \\
\text { services within } \\
\text { DGAPSCs }^{5}\end{array}$ & $\begin{array}{c}\text { Proportion of } \\
\text { services by } \\
\text { total } \\
\text { counties }\end{array}$ \\
\hline Services of social assistance and support ${ }^{1}$ & 17 & $36 \%$ \\
\hline $\begin{array}{l}\text { Services of personal care }{ }^{2} \text { recovery, empowerment and } \\
\text { rehabilitation services (with accommodation }{ }^{3} \text { ) }\end{array}$ & 16 & $34 \%$ \\
\hline $\begin{array}{l}\text { Services of personal care, recovery, empowerment and } \\
\text { rehabilitation services (without accommodation }{ }^{4} \text { ) }\end{array}$ & 38 & $80 \%$ \\
\hline Services of social insertion/reinsertion & 1 & $2 \%$ \\
\hline Training services for work and independent living & 5 & $11 \%$ \\
\hline Other services & 4 & $9 \%$ \\
\hline
\end{tabular}

${ }^{1}$ help for basic daily activities, information, personal care, social and participation integration, housing, assessment, work support services (assisted employment), ensuring access to vocational training programs, other specialized services according to the specific and individual characteristics of people with ASD

2 is addressed to the person with ASD without functional autonomy and who needs support to perform the usual activities of daily living.

${ }^{3}$ can be for a determined or indefinite period: residential centers, sheltered housing, night shelters, respiro centers, etc.

${ }^{4}$ can be day centers, home care services, community services, social canteens, mobile food services, social ambulance, support services, etc.

${ }^{5}$ General Directorates of Social Assistance and Child Protection (DGASPC) at the level of each county.

Note: It is noted that all these types of social services for people with ASD are insufficient, in 2019 there was a county without any type of service (Brașov), and social insertion/ reintegration services as well as training services for work and independent living, were extremely few in 2019.

Source: National Authority for the Protection of the Rights of the Child and Adoption

Paradoxically, there were years when, in some counties, family doctors reported to the National Institute of Public Health no cases of autism: in 2008, in the counties of Sălaj, Argeș, Vrancea, Buzău, Teleorman, Giurgiu, Ialomița, Călărași and Constanța. In 2009, no 
case of a person diagnosed with ASD was reported in the counties: Caraș-Severin, Mehedinți, Dâmbovița, Călărași, Ialomița and Brăila. In 2010, no case of autism was reported by family doctors from Alba, Caraş-Severin, Vrancea, Brăila and Dolj counties. In 2011, Sălaj and Dolj counties did not report any case of autism. In 2012 Dolj was the only county that reported 0 cases of autism, and in 2014 and 2017 Olt County was the only county that reported 0 cases of autism.
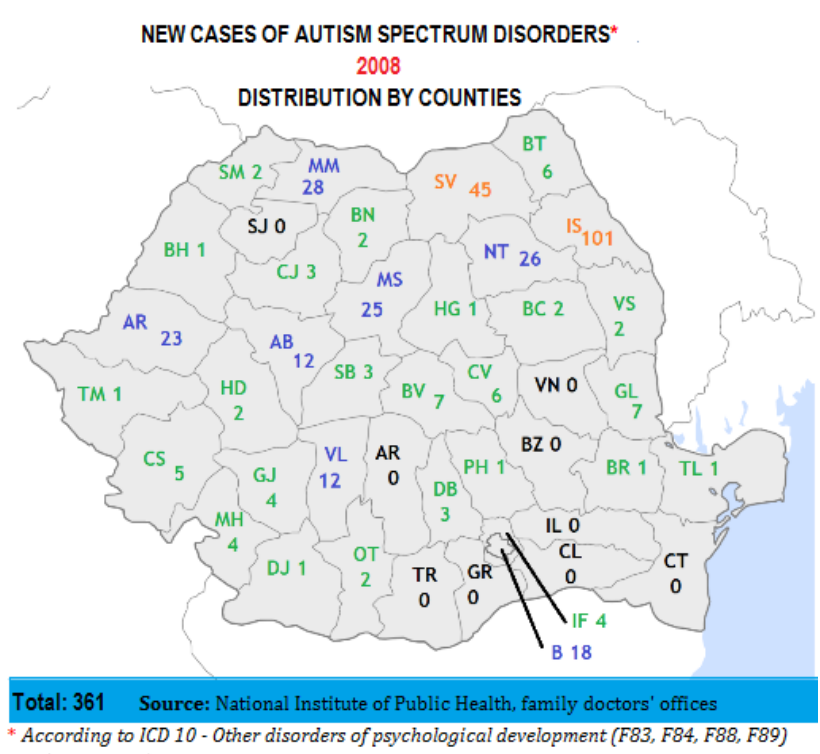

*According to ICD 10 - Other disorders of psychological development (F83, F84, F88, F89)

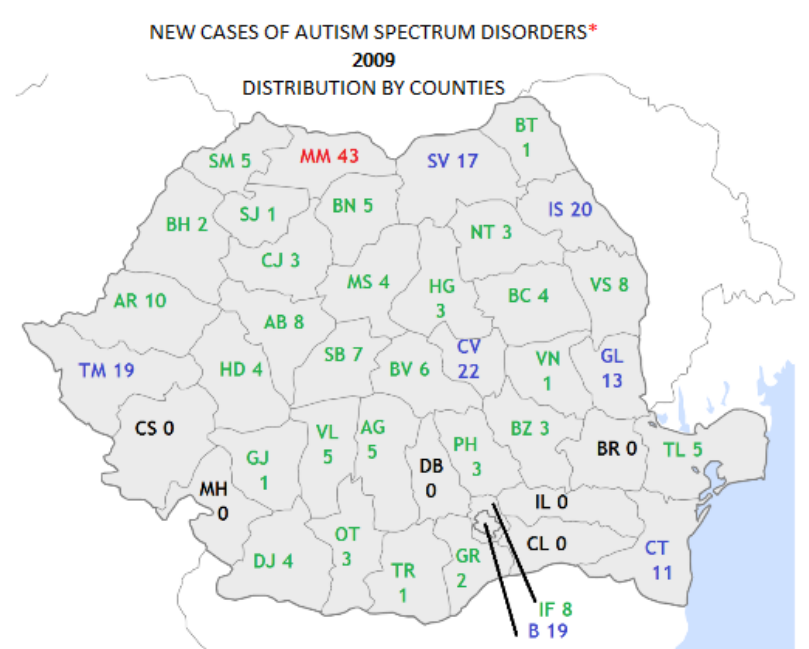

Total: 279 Source: National Institute of Public Health, family doctors' offices

${ }^{*}$ According to ICD 10 - Other disorders of psychological development (F83, F84, F88, F89) 


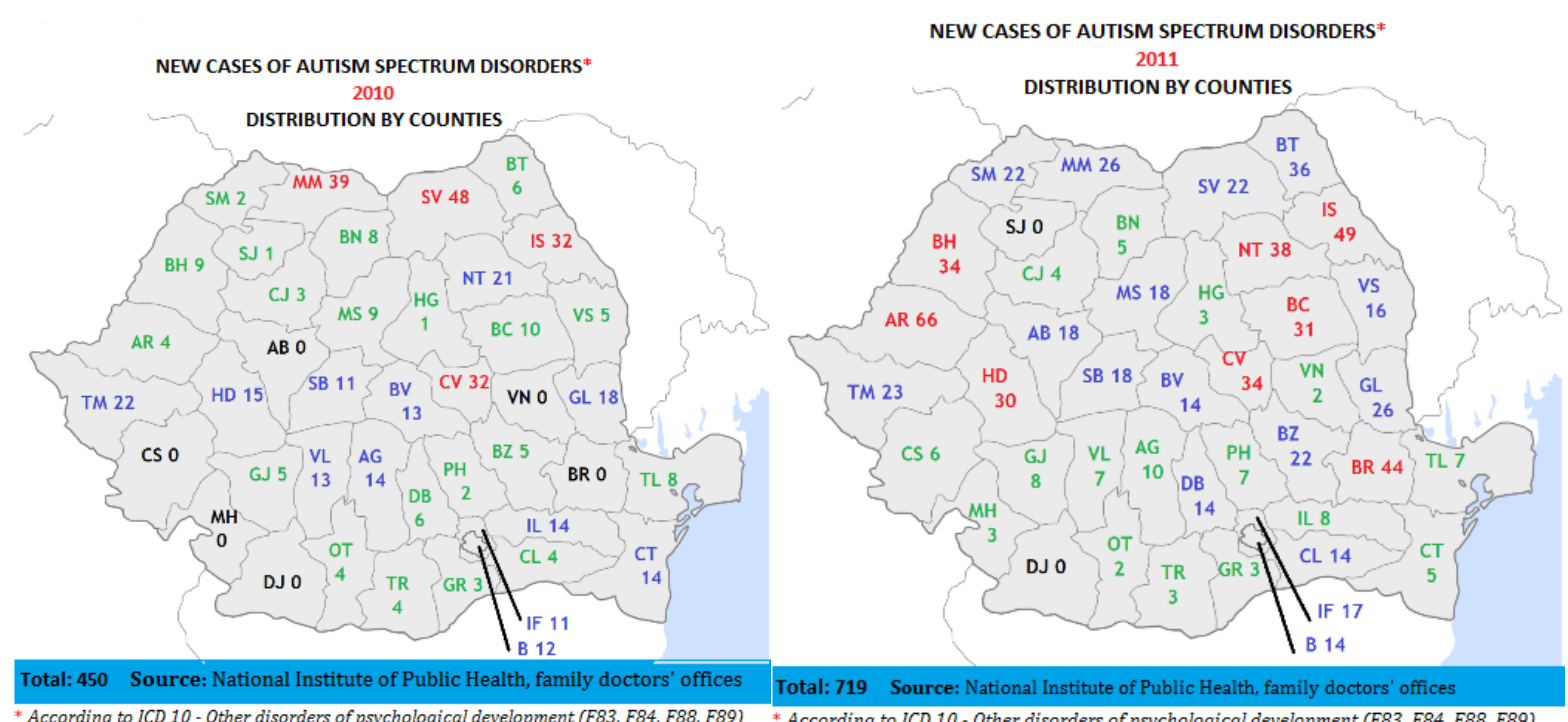

"According to ICD 10 - Other disorders of psychological development (F83, F84, F88, F89) * According to ICD 10 - Other disorders of psychological development (F83, F84, F88, F89)

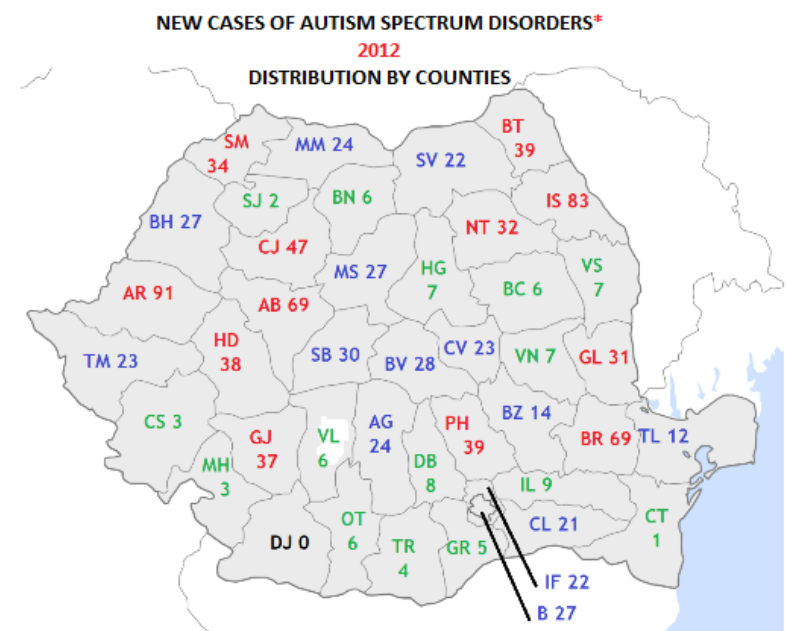

Total: 1013 Source: National Institute of Public Health, family doctors' offices

* According to ICD 10 - Other disorders of psychological development (F83, F84, F88, F89)

NEW CASES OF AUTISM SPECTRUM DISORDERS*

$$
2013
$$

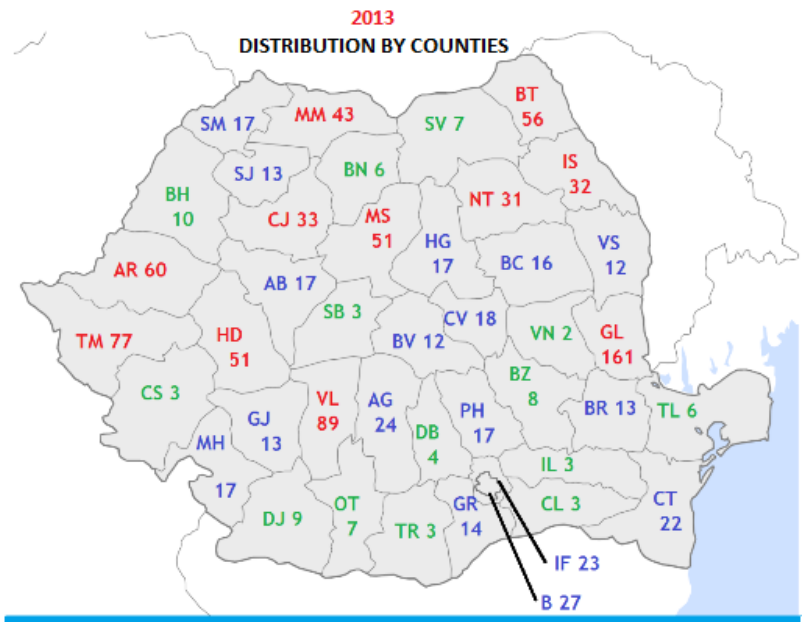

Total: 1050 Source: National Institute of Public Health, family doctors' offices

* According to ICD 10 - Other disorders of psychological development (F83, F84, F88, F89) 


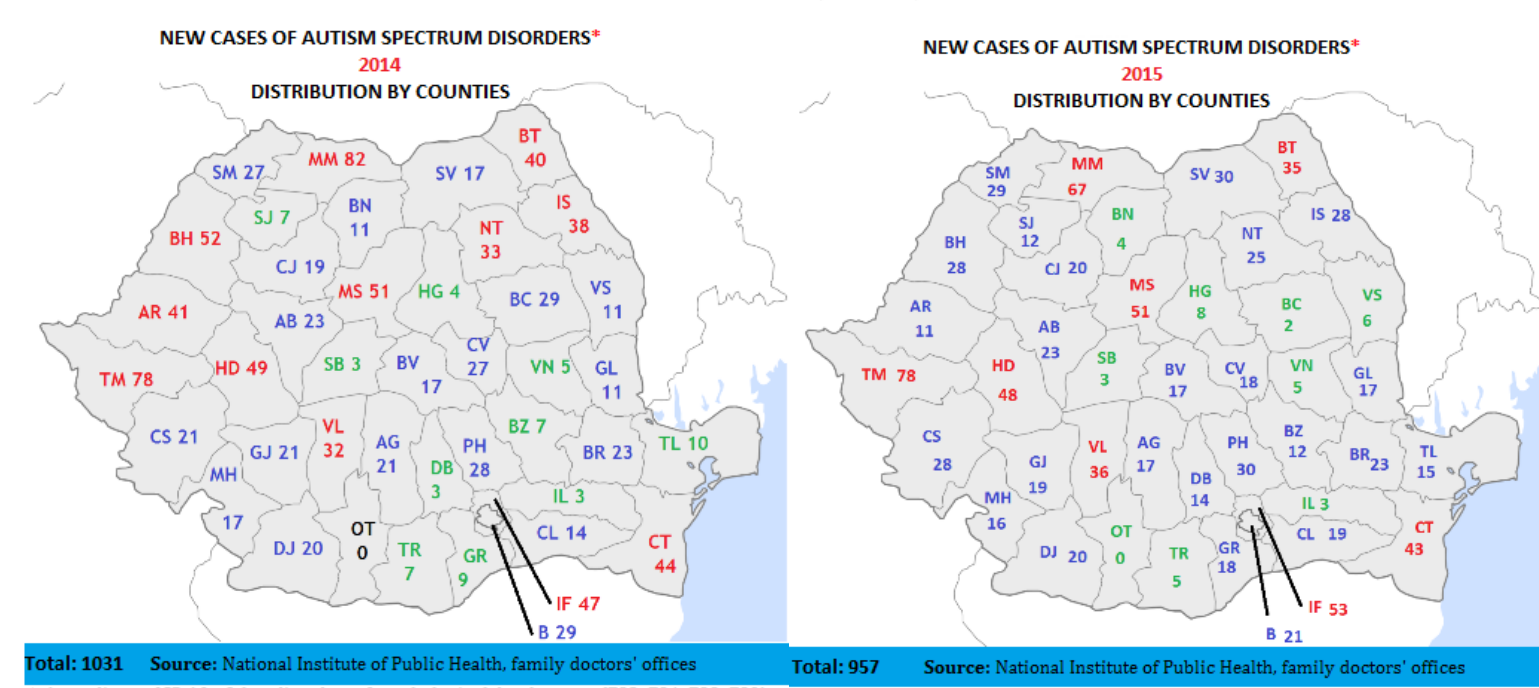

$\begin{array}{lll}\text { Total: } 1031 \text { Source: National Institute of Public Health, family doctors' offices } & \text { Total: } 957 \quad \text { Source: National Institute of Public Health, family doctors' offices } \\ \text { *According to ICD 10 - Other disorders of psychological development (F83, F84, F88, F89) } & \text { *According to ICD 10 - Other disorders of psychological development (F83, F84, F88, F89) }\end{array}$

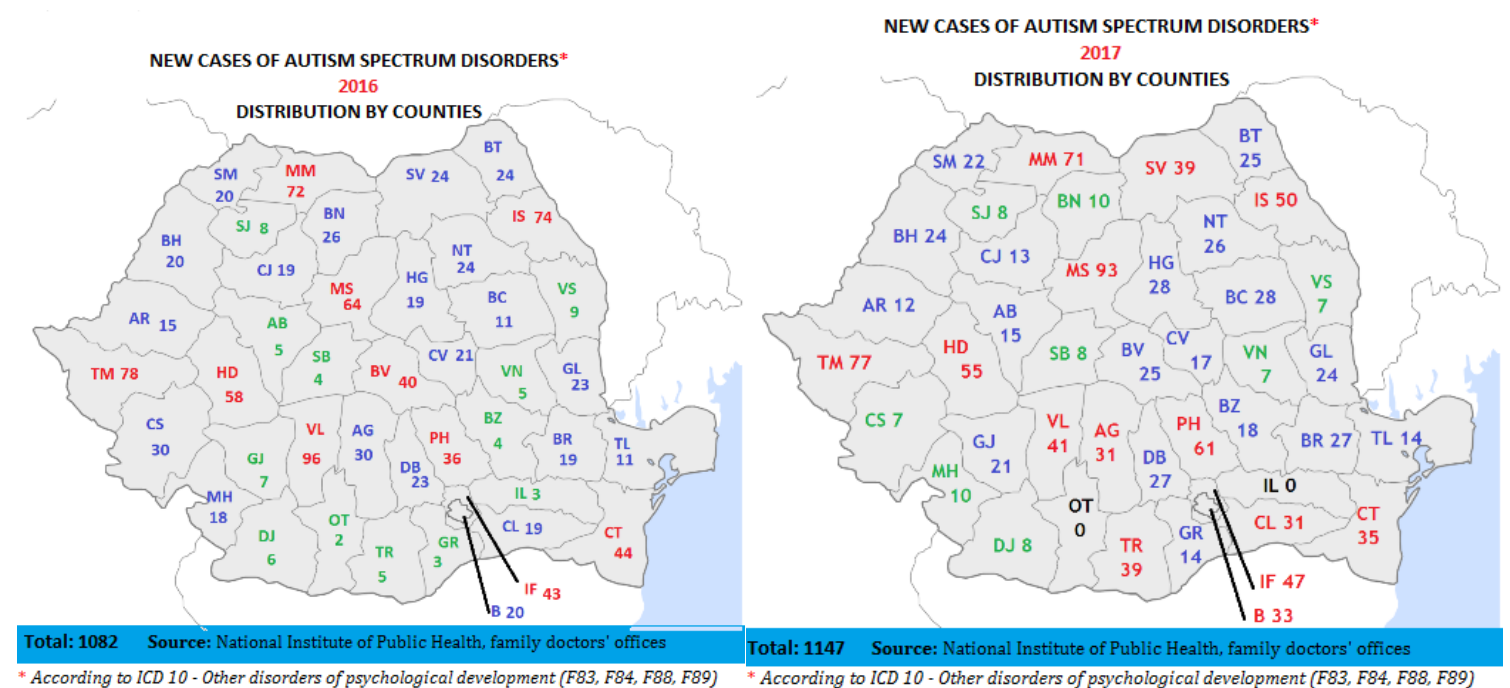

Figure 9. Maps of new cases of ASD in the last 10 years (distribution by counties 20082017)

During the 3 meetings of the inter-ministerial working group, each of the issues identified following the research, focus groups and working meetings in the territory were discussed in turn, on the analysis of current legislation. Thus, the main solution agreed by all specialists involved in the project was to develop a framework for organizing integrated specialized health, education and social services for people with autism spectrum disorders and associated mental health disorders and their standardization. Thus, the discussions revealed the need to configure an effective framework for providing integrated specialized services for children with autism spectrum disorders (ASD).

It was therefore necessary both to develop a public policy to increase children's participation in integrated specialized services and to increase the capacity of civil society (non-governmental organizations) to provide services for children with ASD, on two levels: on the one hand to increase the quality of services provided to children with ASD (by creating a quality standard of integrated specialized services), on the other hand streamlining the collaboration of NGOs in the field with different institutions: MMJS, DGASPCs, ISJs, CJRAE/CMBRAE, CȘEI, Mental Health Centers and with local public 
authorities-town halls through DAS. At the same time, monitoring all activities and services for children with ASD is necessary to ensure that the quality of these services provided to them is maintained.

\section{Discussions and conclusions}

Among the solutions that can be successful in the involvement of NGOs in formulating public policies is to increase their interaction with Parliament, institutions with expertise in the field and other NGOs. Rarely used advocacy method, regular contact with political actors and decision makers can be intensified, especially through coalitions and federations in which NGOs operate. Reality shows us that the recent successes of the civil society sector have been based on constant and persevering communication with political actors and decision-makers. NGOs should adapt better their change requests to the institutional recipients of public policy proposals. The easier these proposals are to be introduced in the decision-making circuit of the respective institution, the more likely it is that their issuer will find an open decision maker to promote them (FDSC, 2017: 112). In the case of this project, although the main objective was to develop an alternative public policy proposal in the field of providing services for children with ASD and their families, Help Autism Association would not have succeeded without the support of an institution that assumed the role of taking over the public policy proposal and further promoting it. In fact, from a legal point of view, only institutions can propose and issue public policy proposals. However, the project "Increasing the involvement of NGOs and social partners in promoting alternative public policies for children with ASD (ONGPP)" implemented by the Help Autism Association is clear evidence that, through a civil society initiative, public policy proposals can be initiated and successfully completed. The project managed to develop the largest network of NGOs in the field and partnerships between civil society (NGO environment) and institutions with responsibilities in the field. The results of the project implementation are spectacular. Thus:

- The capacity of 80 NGOs to get involved in formulating alternative proposals and their constant interest in this direction have increased.

- 151 specialists participating in the regional consultations regarding the analysis of the impact of the legislative regulations in the field.

- 139 specialists from institutions and NGOs participating in the 8 regional debates on problems and identifying solutions for providing services for children with ASD and their families.

- Through the method of the self-administered questionnaire, opinions were collected from 47 specialists from institutions and practitioners from NGOs and 303 answers from the relatives/guardians of people with ASD;

- 134 in-depth interviews with specialists from institutions, practitioners from NGOs and parents of children with ASD;

- 39 NGO representatives acquired the skills to make good use of the advocacy method in order to promote the identified alternatives to current public policies in the field of providing services to children with ASD and their families and were aware of the 
importance of cooperation between NGOs and public authorities to provide the best solutions to the legislative vacuum problems faced by children with ASD and their families.

- 31 representatives from non-governmental institutions and organizations participated in the 3 meetings in working groups, in order to obtain the harmonization of various alternative proposals to public policies and for their analysis in terms of their reality and sustainability.

- An advocacy campaign was implemented with the public consultation of the public policy proposal and the organization of a public debate.

- A meeting was organized with the participation of policy makers in the field to sign an agreement in principle that they will further promote the alternatives proposed by the project to existing public policies in order to support children with ASD and their families.

- An alternative public policy proposal was submitted to the Government for the establishment of Integrated Specialized Health, Education and Social Services for children with ASD and their families.

An unresolved issue in the field of ASD intervention refers to the number of children, young people and adults with these disorders that are not accurately recorded in Romania. The data currently existing in Romania are partial, administrative data, held by some institutions such as DGASPCs (centralized at the level of ANPDCA), the National Institute of Public Health (INSP) through the data provided by family doctors and MEN through CJRAE those who record the number of children with ASD who were issued a certificate of school and vocational guidance, CES certificates (special educational requirements), but all these data in 2019 were not publicly found and, therefore, there were no official published statistics in this area. It is necessary to achieve a centralized record of children/people suffering from ASD by establishing A Registry of People with Autism Spectrum Disorders. The existence of evidence is essential in the unitary approach to the issue of children with ASD. Such a register in which people with ASD are recorded would be an official and accurate source of data that would allow the authorities to determine the best ways to intervene and allocate resources since the number of people, the age of diagnosis, the geographical areas where they emerged, the need for therapies, the degree of disability will be known.

Guiding the parents of the child with ASD in managing the immediate measures to be taken in addressing his recovery, after establishing a diagnosis is essential. Once diagnosed with ASD, the child's parents should be guided/accompanied in the process of accepting the existing situation and establishing the most appropriate therapeutic path necessary for the partial/total recovery of the child, or at least to improve the quality of life for both the child, as well as for his family. In this context, it is useful to create a Methodological Guide for Parents containing information about ASD, about how parents 
should approach the child with ASD, who to address and who to talk to or what therapies are needed.

A first step in carrying out the early intervention will be the diagnosis of ASD in children and, for this, the collaboration between the family doctor of the child and the child's parents is vital. Thus, all family doctors need to know and apply the tools to identify the early signs of ASD in the screening they perform on the health of the children they have in care. At the same time, parents must be involved, in an informed way, in monitoring the health of their children, as they are the ones who can observe the first possible problems that may arise. Specifically, regarding ASD, parents can be instructed to know and follow the normal stages of the child's development and to contact the family doctor as soon as they notice deviations from normal development. Therefore, the good cooperation between the family doctor and the parents creates the premises for diagnosing ASD and early intervention.

Furthermore, the difficult access to therapy for children with ASD is a problem due to the insufficient financial compensation of therapy services by the Ministry of Health through the National Health Insurance House. Establishing a number of therapy hours per day for children with ASD and a settlement on the compensated services, as well as a way to settle the necessary therapies for children with ASD is more than stringent. The costs of the necessary therapies for children with ASD are high and they are, in most cases, supported by the parents of these children. In 2019 there was at the level of the General Directorates of Social Assistance and Child Protection (DGASPC) the possibility to provide free therapies for children with autism, but they consist of a maximum of 2-4 hours per week and only in 38 counties. The need for therapy for these children is greater and therefore, in order to ensure the real access of children to therapies and to improve their chances of recovery, it is necessary to establish a number of hours of therapy per day to be reimbursed from health insurance. CNAS, together with non-governmental organizations in the field, worked on the implementation of the National Subprogram for Autism, which, according to the Protocol signed on April 2nd 2019, provides mechanisms and steps to reimburse medical services especially for children with ASD.

\section{Acknowledgments}

The article was written following the author's participation in the Project "Increasing the involvement of NGOs and social partners in promoting alternative public policies for children with ASD (ONGPP)", SIPOCA 313/110709 project funded by the European Social Fund (ESF) through the Operational Program Administrative Capacity (POCA) of the European Union, implemented by the Help Autism Association (HA), Bucharest in partnership with the National Authority for the Protection of Children's Rights and Adoption (ANPDCA) between July 2018 - November 2019. Thanks to Marian Sîrbu (project initiator), Daniela Bololoi (president of the Help Autism Association), Zvetlana Zara (project manager), public policy experts Silvia Dumitrean, Ioana Leșe, Cosmin Radu, Oana Mîndruț, Maria Moța, Septimius Pârvu, the main counselors, psych. Adina Codreș 
and Dr. Isabela Popa (ANPDCA), as well as all those who made possible the implementation of the project.

\section{References}

Autism Speaks. (2020). Report of The Centers for Disease Control and Prevention (CDC) https://www.autismspeaks.org/press-release/cdc-estimate-autism-prevalence-increasesnearly-10-percent-1-54-children-us?utm source=email\&utm medium=text-

link\&utm campaign=CDC, accessed in September 2021.

Behavior Analyst Certification Board (2019). The list of Romanian specialists in BCBA:

https://www.bacb.com/services/o.php?page=100155\&by=country, accessed on August 2019.

Federation for the Rights and Resources of Persons with Autism Spectrum Disorders, https://www.autismfedra.ro/en/, accessed in August 2019

Foundation for the Development of Civil Society, (2017). Romania 2017. Non-Governmental Sector profile, trends, challenges, p. 109, available at http://fondong.fdsc.ro/upload/Stiri\%20generale/Romania\%202017.pdf, accessed in August 2019.

Gazibar M. (coord.); Petrescu C.; Neguț A.; Stănilă G. (2018). The Welfare of the Child from Rural Areas (Bunăstarea copilului din mediul rural), p. 54, available athttps://worldvision.ro/media/presa/studii-sirapoarte/Bunastarea copilului din mediul rural 2018.pdf, accessed on 4.07.2019.

Government of Romania, (2018). Press release, http://gov.ro/ro/stiri/comunicat-depresa1518769098, accessed in August 2019.

https://stirileprotv.ro/stiri/politic/dancila-despre-cei-care-zdezinformeaza-la-bruxelles-zacestioameni-sunt-autisti.html

Help Autism Association, (2019). Advocacy Campaign,

http://paca.helpautism.ro/viewforum.php?f=13\&sid=99629d861e62f78e202db46fecfca624, accessed in August 2019

http://paca.helpautism.ro/viewtopic.php?f=13\&t=62, accessed in August 2019.

Help Autism Association, Needs Analysis Report in the Field of Providing Integrated Services for People with Autism Spectrum Disorders (ASD) 2019. Proposed Solutions, http://paca.helpautism.ro/viewtopic.php? $\mathrm{f}=10 \& \mathrm{t}=44$, accessed in August 2019.

Help Autism Association, Qualitative Report on the Needs of People with ASD - 2019, Interviews with Relatives of People with ASD and Specialists from Institutions and NGOs http://paca.helpautism.ro/viewtopic.php?f=10\&t=43, accessed in August 2019.

National Health Insurance House, (CNAS) http://www.cnas.ro/post/type/local/mesajul-cnas-de-ziuamondiala-a-con-tientizarii-autismului.html, accessed in April 2019.

National Council for Combating Discrimination, (2018). Press release,

http://cncd.org.ro/2018-02-16-comunicat-de-presa-referitor-la-declaratia-doamnei-prim-ministrudancila-viorica-vasilica-din-data-15-februarie-2018, accessed on 5.08.2019.

National Council for Combating Discrimination, (2018), http://cncd.org.ro/2018-02-26-comunicat-depresa-referitor-la-hotararea-adoptata-de-colegiul-director-al-cncd-in-edin-a-din-data-de-26-022018, accessed in August 2019.

Ministry of Health, http://www.ms.ro/2019/04/02/servicii-integrate-de-sanatate-sociale-si-deeducatie-pentru-pacientii-cu-tulburari-de-spectru-autist/, accessed on 6.04.2019.

Ministry of National Education, Press release, https://www.edu.ro/marcarea-zileiinterna\%C8\%9Bionale-de-con\%C8\%99tientizare-autismului-prin-semnarea-protocolului-decolaborare, accessed in April 2019. 
Ministry of Labor and Social Justice (MMJS), Register of Social Services, https://serviciisociale.gov.ro/source/Registru/08.07.2019 Servicii Sociale.pdf, accessed on 31.07.2019

Parliament of Romania, LAW no. 544 of October 12, 2001 on free access to information of public interest, http://legislatie.just.ro/Public/DetaliiDocument/31413, accessed in August 2019.

Parliament of Romania, LAW no. 52 of 21 January 2003 ( ${ }^{*}$ republished *) on decision-making transparency in public administration *), http://legislatie.just.ro/Public/DetaliiDocument/41571, accessed in August 2019.

Romanian Angel Appeal Association (2013). Evaluation report of the services offered in the counseling and assistance centers for people with autism spectrum disorders, opened within the POSDRU 60289 project "They must have a chance, too - a support program for social and professional integration of people with autism spectrum disorders"

http://autism.raa.ro/upload/files/Raport Evaluarea serviciilor oferite in centrele ASD.pdf, accessed in July 2019

Romanian College of Psychologists (2019a). https://alegericpr.ro/images/files/comisii/Norme TSA certificare competente in autism aprobate in sedinta CD din 07.06.2019.pdf accessed in June 2019

Romanian College of Psychologists (2019b). https://alegericpr.ro/index.php/comunicare/4209norme-certificare-competente-in-autism-si-procedura-de-inregistrare, accessed in August 2019

World Health Organisation (2019). https://www.who.int/news-room/fact-sheets/detail/autismspectrum-disorders, accessed in September 2021.

*** Order no. 397/836/2018 regarding the approval of the Methodological Norms for the application in 2018 of the Government Decision no. 140/2018 for the approval of the service packages and of the Framework Contract that regulates the conditions for providing medical assistance, medicines and medical devices within the social health insurance system for the years 2018-2019.

*** Autism Law, Law no. 151 of 12 July 2010 on integrated specialized health, education and social services for people with autism spectrum disorders and associated mental health disorders, accessed on https://autismvoice.ro/portfolio-items/lege-nr-151-din-12-iulie-2010-privindserviciile-specializate-integrate-de-sanatate-educatie-si-sociale-adresate-persoanelor-cutulburari-din-spectrul-autist-si-cu-tulburari-de-sanatate-mintala-asoc/?portfolioCats=328 and entered into force on 1 January 2011.

*** Norms for the application of the Autism Law, Methodological norms from August 25, 2016 for the application of Law no. 151/2010 on specialized integrated health, education and social services for people with autism spectrum disorders and associated mental health disorders, https://autismvoice.ro/portfolio-items/norme-metodologice-din-25-august-2016-de-aplicarelegii-nr-1512010-privind-serviciile-specializate-integrate-de-sanatate-educatie-si-socialeadresate-persoanelor-cu-tulburari-din-spectrul-autist/?portfolioCats=328 accessed in July 2019 